\title{
Ionoregulatory Impairment in African Catfish (Clarias gariepinus) Exposed to Combined Stressors of Lead and Cypermethrin
}

\author{
Omowumi O. ADEWALE ${ }^{1}$, Joseph A. ADEYEMI ${ }^{2 *}$ \\ ${ }^{1}$ Department of Chemical Sciences, College of Science, Engineering and Technology, Osun State University, Osogbo, Osun State, Nigeria; \\ ${ }^{2}$ Department of Biological Sciences, College of Science, Engineering and Technology, Osun State University, Osogbo, Osun State, \\ Nigeria; joseph.adeyemi@gmail.com ( ${ }^{*}$ corresponding author)
}

\begin{abstract}
The contamination of aquatic ecosystem with heavy metals and pesticides has increased dramatically over the years, and this has generated a lot of attention by environmental experts. There are reports on impacts of different single toxicants on aquatic organisms but not much has been done to investigate the impacts of mixtures of toxicants on aquatic life. In this study we investigated the effects of multiple stressors of $\mathrm{Pb}$ and cypermethrin on ionoregulation in the African catfish (Clarias gariepinus). Adults C. gariepinus were exposed to either borehole water (control), $2 \mathrm{mg} / \mathrm{L} \mathrm{Pb}, 0.5 \mu \mathrm{g} / \mathrm{L}$ cypermetrin or a mixture of $2 \mathrm{mg} / \mathrm{L} \mathrm{Pb}$ and $0.5 \mu \mathrm{g} / \mathrm{L}$ cypermethrin for $96 \mathrm{~h}$, after which the levels of plasma $\mathrm{Na}^{+}, \mathrm{Cl}^{-}$and $\mathrm{K}^{+}$were determined as a measure of branchial ionoregulatory disturbance. The exposure of C. gariepinus to $0.5 \mu \mathrm{g} / \mathrm{L}$ cypermethrin resulted in a significant reduction in plasma $\mathrm{Na}^{+}\left(43 \%\right.$ decrease) and $\mathrm{Cl}^{-}$(31\% decrease) but a 2-fold increase in plasma $\mathrm{K}^{+}$concentrations. Exposure to a mixture of cypermethrin and $\mathrm{Pb}$ resulted in $53 \%$ decrease in plasma $\mathrm{Na}^{+}, 40 \%$ decrease in plasma $\mathrm{Cl}^{-}$and a 3fold increase in plasma $\mathrm{K}^{+}$. There was no significant difference between the control and those exposed to just only $2 \mathrm{mg} / \mathrm{L} \mathrm{Pb}$ for all the parameters measured. The results of this study indicated that exposure of aquatic organisms to combined stressors of heavy metals pollution as well as pesticide contaminantion could have a serious effect on the physiology especially on ionic regulation in the exposed fish.
\end{abstract}

Keywords: fish, ionoregulation, multiple stressors, plasma electrolytes

\section{Introduction}

The rate of toxic substances released in the environment has increased rapidly due to various human activities (Chakkaravarthy, 2003). The advancement in technology and increased global industrialization has increased the production of toxic heavy metals e.g. lead, and the aquatic environments often serve as the sink for these substances (Sobha et al., 2007). In the recent times, there have been a noticeable increase in the usage of agricultural pesticides, this could be in response to increasing global population which have exerted more pressure on human to respond to the attendant problem of food insecurity arising from global population explosion (Pimentel, 2001). There is the lure to overuse these agricultural chemicals such that they may bioaccumulate at toxic levels in the environments. While pesticides and other agricultural chemicals are not often applied directly into the aquatic environment, they may eventually get into water bodies through leaching and run-offs, thus posing serious risks to resident aquatic organisms (Forstner and Prosi, 1979).

The gill is the major site of ionoregulation in fish but unfortunately it serves as the primary target for the acute toxic action of contaminants (Evans et al., 2005). For example, the exposure of a freshwater fish, rainbow trout to copper impaired branchial ionoregulation by both inhibiting the active transport of $\mathrm{Na}^{+}$and $\mathrm{Cl}^{-}$, and increasing the ionic permeability of the gills which results in a net loss of these ions (Lauren and McDonald, 1985; Lauren and McDonald, 1986). Lead is a nonbiodegradable naturally occurring heavy metal and may potentially become accumulated in various tissues of aquatic organisms. There are reports on the toxicity of $\mathrm{Pb}$ in fish; alteration of biochemical and haematological parameters in the rainbow trout (Ates et al., 2008), oxidative stress in Clarias batrachus (Maiti et al., 2010), histological changes in the gills of neotropical fish, Prochilodus lineatus (Martinez et al., 2004) and behavioural alteration in the rainbow trout (Weber et al., 1997). Cypermethrin is a synthetic pyrethroid insecticides, which have widespread application in the control of insects and pest in agriculture, in homes, and in the garden. It has been proposed as possible alternatives to some organochlorine insecticides, that have been prohibited in many countries (Jee et al., 2005). 
As a result of its numerous applications, the potential of its discharge into the aquatic environment has increased and there are reports that cypermethrin is extremely toxic to fish (David et al., 2004).

Most studies on the effects of environmental pollutants are limited to reporting the effects of either pesticide treatment or metal exposure individually, and only few reports are available on the effects of multiple stressors of pesticides contamination and heavy metal pollution on aquatic organisms. Studying the effects of mixture of contaminants on organisms is particularly necessary because aquatic organisms are exposed to combinations of stressors in their environment. This study is therefore designed to investigate the joint effects of a pyrethroid insecticide, cypermethrin and a heavy metal, lead $(\mathrm{Pb})$ on ionoregulation in the African catfish, Clarias gariepinus.

\section{Materials and methods}

\section{Experimental organisms and contaminant exposure}

Adult catfish ( $n=80)$ of average weight $300 \pm 10$ g were collected from a commercial fish hatchery located in Abere, Osun State, Nigeria $\left(07^{\circ} 43^{\prime} 55 \mathrm{~N} ; 004^{\circ} 31^{\prime} 07 \mathrm{E}\right)$. They were transported live in plastic containers to the Biology Laboratory of the Department of Biological Sciences of the Osun State University, Osogbo, Nigeria. In the laboratory, fish were divided into four groups of about twenty fish per group; control, $2 \mathrm{mg} / \mathrm{L} \mathrm{Pb}, 0.5 \mu \mathrm{g} / \mathrm{L}$ cypermethrin and $2 \mathrm{mg} / \mathrm{L} \mathrm{Pb}+0.5 \mu \mathrm{g} / \mathrm{L}$ cypermethrin. Fish were acclimatized to laboratory conditions for seven days prior to commencement of experiments. During acclimatization, water was exchanged every $24 \mathrm{~h}$ and fish were fed with commercial fish pellets twice daily. At the end of the sevenday acclimatization period, fish were exposed to either borehole water (control), $2 \mathrm{mg} / \mathrm{L} \mathrm{Pb}, 0.5 \mu \mathrm{g} / \mathrm{L}$ cypermethrin or $2 \mathrm{mg} / \mathrm{L} \mathrm{Pb}+0.5 \mu \mathrm{g} / \mathrm{L}$. The choice of the concentrations stated above for each of this compound was due to the available toxicity data that have been reported for a similar fish species in literature (Olaifa et al., 2003; Stephenson, 1982). Experiments were conducted in $7.5 \mathrm{~L}$ plastic buckets, and there were three replicates for each treatment group of about 6-7 adult fish per bucket. Contaminant exposure followed an acute exposure and lasted for $96 \mathrm{~h}$.

\section{Blood collection and plasma ions determination}

At the end of the $96 \mathrm{~h}$ exposure to contaminants, fish were mildly anaesthetized with benzocaine, and blood samples were collected from the caudal vein of each fish. The blood was collected in anticoagulant centrifuge tubes. Plasma was obtained by centrifugation of blood at $3,000 \mathrm{rpm}$ for $10 \mathrm{~min}$. The plasma samples were then stored at $-20^{\circ} \mathrm{C}$ until analysis. The levels of plasma $\mathrm{Na}^{+}$ and $\mathrm{K}^{+}$were determined by flame photometry (Jenway PFP clinical flame photometer) while the plasma $\mathrm{Cl}^{-}$ion level was measured spectrophotometrically using the method reported by Yokoi (2002).

\section{Statistical analyses}

The data were checked for normality using the Shapiro-
Wilk test and there was no significant deviation from normal distribution. The differences in the mean plasma $\mathrm{Na}^{+}, \mathrm{K}^{+}$and $\mathrm{Cl}^{-}$levels among the groups were detected using a one-way analysis of variance (ANOVA) test, this was followed by Tukey's multiple comparison tests whenever there was a significant difference. All statistics were performed using the SPSS version 10.0 statistical software (SPSS Inc., Chicago, IL, USA). Differences were considered significant at $p \leq 0.05$. Data were presented as mean \pm standard deviation.

\section{Results}

The plasma $\mathrm{Na}^{+}$levels differed significantly among the groups $\left(F_{3,16}=54.76 ; p=0.0006\right)$. Fish exposure to 0.5 $\mu \mathrm{g} / \mathrm{L}$ cypermethrin resulted in a significant decrease (43\%) in plasma $\mathrm{Na}^{+}$level compared to the control ( $\mathrm{p}<$ $0.001)$. The decrease was even more pronounced in the group exposed to the mixture of cypermethrin and 2 $\mathrm{mg} / \mathrm{L} \mathrm{Pb}(53 \%)$. There was no significant difference in plasma $\mathrm{Na}^{+}$levels between the group exposed to $2 \mathrm{mg} / \mathrm{L}$ $\mathrm{Pb}$ and the control (Fig. 1). Again, we observed a significant difference in plasma $\mathrm{Cl}^{-}$levels among the exposure groups $\left(\mathrm{F}_{3,16}=8.7649 ; \mathrm{p}=0.0046\right)$. The plasma $\mathrm{Cl}^{-}$levels followed a similar trend observed for the plasma $\mathrm{Na}^{+}$levels. Contaminant exposure caused a significant reduction in plasma $\mathrm{Cl}^{-}$. There was approximately $31 \%$ decrease in plasma $\mathrm{Cl}^{-}$level in the group exposed to only $0.5 \mu \mathrm{g} / \mathrm{L}$ cypermethrin whereas exposure to a mixture of cypermethrin and $\mathrm{Pb}$ resulted in $40 \%$ decrease in the plasma $\mathrm{Cl}^{-}$levels. Exposure to $2 \mathrm{mg} / \mathrm{L} \mathrm{Pb}$ resulted in approximately $11 \%$ decrease in the plasma $\mathrm{Cl}^{-}$levels (Fig. 2).

While contaminant exposure resulted in a decrease in the levels of plasma $\mathrm{Na}^{+}$and $\mathrm{Cl}^{-}$however exposure tended to significantly increase the levels of plasma $\mathrm{K}^{+}$levels in $C$. gariepinus $\left(\mathrm{F}_{3,16}=5.6274 ; \mathrm{p}=0.0096\right)$. Exposure to $5 \mu \mathrm{g} / \mathrm{L}$ cypermethrin resulted in approximately 2 -fold increase in the plasma $\mathrm{K}^{+}$levels while exposure to a mixture of cypermethrin and $2 \mathrm{mg} / \mathrm{L} \mathrm{Pb}$ resulted in a 3-fold increase in the plasma $\mathrm{K}^{+}$levels. There was no significant change in the plasma $\mathrm{K}^{+}$levels between the group exposed to $2 \mathrm{mg} / \mathrm{L} \mathrm{Pb}$ and the control (Fig. 3).

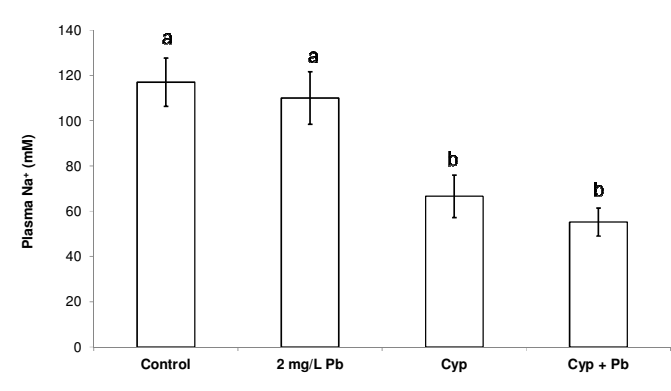

Fig. 1. Mean $( \pm \mathrm{SE}, \mathrm{n}=6)$ plasma $\mathrm{Na}^{+}$in $C$. gariepinus exposed to either borehole water (control), $2 \mathrm{mg} / \mathrm{L} \mathrm{Pb}, 0.5 \mu \mathrm{g} / \mathrm{L}$ cypermethrin or $0.5 \mu \mathrm{g} / \mathrm{L}$ cypermethrin $+2 \mathrm{mg} / \mathrm{L} \mathrm{Pb} .(\mathrm{n}=6)$. Bars with different letters are significantly different 


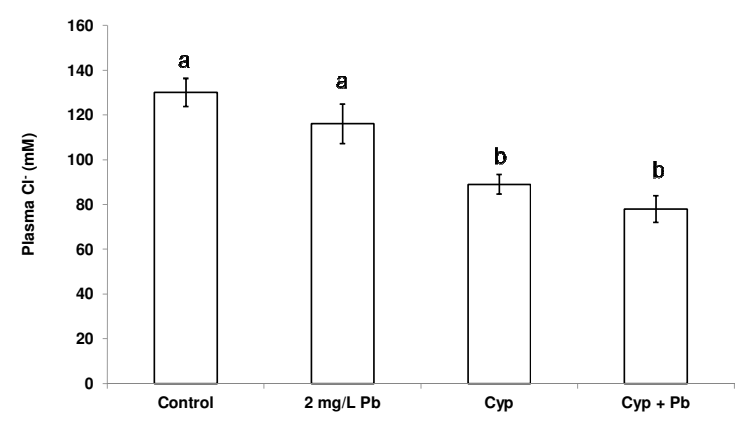

Fig. 2. Mean $( \pm \mathrm{SE}, \mathrm{n}=6)$ plasma $\mathrm{Cl}^{-}$in $C$. gariepinus exposed to either borehole water (control), $2 \mathrm{mg} / \mathrm{L} \mathrm{Pb}, 0.5 \mu \mathrm{g} / \mathrm{L}$ cypermethrin or $0.5 \mu \mathrm{g} / \mathrm{L}$ cypermethrin $+2 \mathrm{mg} / \mathrm{L} \mathrm{Pb}$.. Bars with different letters are significantly different

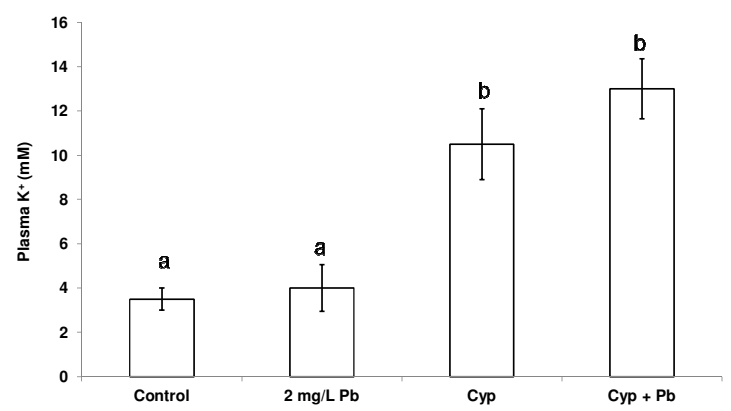

Fig. 3. Mean $( \pm \mathrm{SE}, \mathrm{n}=6)$ plasma $\mathrm{K}^{+}$in $C$. gariepinus exposed to either borehole water (control), $2 \mathrm{mg} / \mathrm{L} \mathrm{Pb}$, $0.5 \mu \mathrm{g} / \mathrm{L}$ cypermethrin or $0.5 \mu \mathrm{g} / \mathrm{L}$ cypermethrin $+2 \mathrm{mg} / \mathrm{L}$ $\mathrm{Pb}$. Bars with different letters are significantly different

\section{Discussion}

The results of this study showed that exposure of $C$. gariepinus to either $0.5 \mu \mathrm{g} / \mathrm{L}$ cypermethrin or a mixture of cypermethrin and $\mathrm{Pb}$ resulted in ionic disturbance, revealed by imbalance in the levels of important plasma ions. Current understanding holds that the osmo/ionoregulatory disturbances induced by pesticides and metals were associated with an increased epithelial permeability and inhibition of active ion uptake, which may result in a significant decrease in the number of active chloride cells (De Boeck et al., 2001; Monteiro et al. 2005). There are reports that exposure of fish to certain heavy metals competitively inhibited the activity of $\mathrm{Na}^{+} / \mathrm{K}^{+}$-ATPase, a tetrameric protein that is located in the basolateral region of the gills and that have been shown to be actively involved in ionic regulation in teleosts (Adeyemi et al., 2012; Atli and Canli, 2011). Fish exposure to $\mathrm{Pb}$ or cypermethrin caused a drastic loss of both plasma $\mathrm{Na}^{+}$and $\mathrm{Cl}^{-}$. This is particularly as expected since it has been reported that plasma $\mathrm{Na}^{+}$and $\mathrm{Cl}^{-}$tend to be similarly affected by waterborne toxicants (McDonald et al., 1989). The ionoregulatory disturbance was more pronounced in the group that was exposed to the mixture of cypermethrin and $\mathrm{Pb}$, thus ascertaining the complex effects of exposure to multiple stressors in an aquatic ecosystem. This therefore necessitates the need for development of more models that could be used to extrapolate the effects of exposure to multiple stressors in ecological risk assessment, since most of the available models concentrates on the effects of a single stressor which is very far from the situation in most aquatic ecosystems where organisms are exposed to a wide array of xenobiotics simultaneously.

There was no evidence that exposure of C. gariepinus to $2 \mathrm{mg} / \mathrm{L} \mathrm{Pb}$ resulted in a significant decrease in the levels of plasma ions in this study. This may be an indication that this exposure concentration $(2 \mathrm{mg} / \mathrm{L} \mathrm{Pb})$ is too low to elicit such physiological disturbance in this fish. Firat et al. (2011) showed that exposure of Nile Tilapia to even a lower concentration of $\mathrm{Pb}(0.05 \mathrm{mg} / \mathrm{L}$ $\mathrm{Pb}$ ) did cause a significant reduction in the levels of plasma $\mathrm{Na}^{+}$and $\mathrm{Cl}^{-}$although this effect was observed during longer exposure periods It may therefore be inferred that C. gariepinus is not as sensitive to environmental contamination as other surrogate fish species. However, caution must be taken before generalizing that $C$. gariepinus is not as sensitive to environmental contamination as other surrogate fish species since the current study followed an acute exposure; the result could be quite different if the experiment followed a chronic exposure.

The plasma $\mathrm{K}^{+}$levels increased significantly in groups that were exposed to either cypermethrin alone or a mixture of cypermethrin and $\mathrm{Pb}$. This is consistent with the findings of Bernard and Grazyna (1999) and Firat et al. (2011) whose studies showed that plasma $\mathrm{K}^{+}$levels actually increased in fish following exposure to heavy metals and pesticides The excessive accumulation of $\mathrm{K}^{+}$ in the plasma of exposed fish could be an indication of renal disturbance in this fish, since $\mathrm{K}^{+}$is normally excreted by the kidneys.

In conclusion, exposure of $C$. gariepinus to either cypermethrin or a mixture of cypermethrin and $\mathrm{Pb}$ at concentrations tested in this study was found to cause impairment of ionoregulation. The ionic disturbance was not detected in C. gariepinus that were exposed to only 2 $\mathrm{mg} / \mathrm{L} \mathrm{Pb}$. The additive effects of exposure to mixture of cypermethrin and $\mathrm{Pb}$ in this study re-emphasizes the need to direct more attention towards including more data on mixture toxicity as a first step towards a more robust risk assessment.

\section{References}

Adeyemi JA, Deaton LE, Pesacreta TC, Klerks PL (2012). Effects of copper on osmoregulation in sheepshead minnow, Cyprinodon variegatus acclimated to different salinities. Aquat Toxicol 109:111-117.

Ates B, Orun I, Talas ZS, Durmaz G, Yilmaz I (2008). Effects of sodium selenite on some biochemical and hematological parameters of rainbow trout (Oncorbynchus mykiss Walbaum, 1792) exposed to $\mathrm{Pb}^{2+}$ and $\mathrm{Cu}^{2+}$. Fish Physiol Biochem 34:53-59.

Atli G, Canli M (2011). Essential metal (Cu, Zn) exposures alter the activity of ATPases in gill, kidney and muscle of 
tilapia Oreochromis niloticus. Ecotoxicology 20:1861-1869.

Bernard K, Grazyna L (1999). Effect of a sublethal concentration of deltametrin on biochemical parameters of the blood serum of carp (Cyprinus carpio L.). Acta Ichthyol Piscat 29:109-117.

Chakkaravarthy Q (2003). Human Survival and Environmental Pollution. In: Bunch MJ, Madha S, Kumaran TV Eds. Proceedings of the Third International Conference on Environment and Health, Chennai, India, 15-17 December, 2003. Chennai: Department of Geography, University of Madras and Faculty of Environmental Studies, York University, p. 66-74.

David M, Mushigeri SB, Shivakumar R, Philip GH (2004). Response of Cyprinus carpio (Linn) to sublethal concentration of cypermethrin: alterations in protein metabolic profiles. Chemosphere 56:347-352.

De Boeck G, Vlaeminck A, Balm PH, Lock RA, Wachter B, Blust $\mathrm{R}$ (2001). Morphological and metabolic changes in common carp, Cyprinus carpio, during short-term copper exposure: interactions between $\mathrm{Cu}^{2+}$ and plasma cortisol elevation. Environ Toxicol Chem 20:374-381.

Evans DH, Piermarini PM, Choe KP (2005). The multifunctional fish gill: dominant site of gas exchange, osmoregulation, acid-base regulation and excretion of nitrogenous wastes Physiol Rev 85:97-177.

Firat O, Cogun HY, Yuzereroglu TA, Gok G, Firat O, Kargin F, Kotemen Y (2011). A comparative study on the effects of a Pesticide (cypermethrin) and two metals (copper, lead) to serum biochemistry of Nile tilapia, Oreochromis niloticus. Fish Physiol Biochem 37:657-666.

Forstner U, Prosi F (1979). Heavy metal pollution in freshwater ecosystem. In "Biological aspects of Freshwater Pollution". Pergamon Press (Oxford).

Jee JH, Masroor F, Kang JC (2005). Responses of cypermethrininduced stress in haematological parameters of Korean rockfish, Sebastes schlegeli (Hilgendorf). Aquatic Research 36:898-905.

Laurén DJ, McDonald DG (1985). Effects of copper on branchial ionoregulation in the rainbow trout, Salmo gairdneri Richardson. Modulation by water hardness and pH. J Comp Physiol B 55:635-644.
Laurén DJ, McDonald DG (1986). Influence of water hardness, $\mathrm{pH}$, and alkalinity on the mechanisms of copper toxicity in juvenile rainbow trout, Salmo gairdneri. Can J Fish Aquat Sc 43:1488-1496.

Maiti AK, Saha NC, Paul G (2010). Effect of lead on oxidative stress, $\mathrm{Na}+\mathrm{K}+\mathrm{ATP}$ ase activity and mitochondrial electron transport chain activity of the brain of Clarias batrachus $\mathrm{L}$. Bull Environ Contam Toxicol 84:672-676.

Martinez CB, Nagae MY, Zaia CT, Zaia DA(2004). Acute morphological and physiological effects of lead in the neotropical fish Prochilodus lineatus. Braz J Biol 64:797807.

McDonald DG, Reader JP, Dalziel TR (1989). The combined effects of $\mathrm{pH}$ and trace metals on fish ionoregulation. In: Morris $\mathrm{R}$ et al. (Eds.). Acid toxicity and aquatic animals. Society of Experimental Biologist Seminar Series 31:221242.

Monteiro SM, Mancera JM, Fernandes AF, Sousa M (2005). Copper induced alterations of biochemical parameters in the gill and plasma of Oreochromis niloticus. Comp Biochem Physiol C 141:375-383.

Olaifa FE, Olaifa AK, Lewis OO (2003). Toxic stress of lead on Clarias gariepinus (African catfish) fingerlings. African Jf Biom 6:101-104.

Pimentel D (2001). Overview of the use of genetically modified organisms and pesticides in agriculture. Ind J Global Legal Stud 9:51-64.

Sobha K, Poornima A, Harini P, Veeraiah K (2007). A study on the biochemical changes in freshwater fish Catla catla exposed to the heavy metal toxicant, cadmium chloride. Kathmandu University J Sci Engineer Technol 3:1-11.

Stephenson RR (1982). Aquatic toxicology of cypermethrin. I. Acute toxicity to some freshwater fish and invertebrates in laboratory tests. Aquat Toxicol 2:175-185.

Weber DN, Dingel WM, Panos JJ, Steinpreis RE (1997). Alterations in neurobehavioural responses in fishes exposed to lead and lead-chelating agents. Amer Zool 37:354-362.

Yokoi K (2002). Colorimetric determination of chloride in biological samples by using mercuric nitrate and diphenylcarbazone. Biol Trace Elem Res 85:87-94. 